\title{
Self-Sacrifice between Constraint and Redemption: Gertrud von Le Fort's The Song at the Scaffold
}

\author{
MarcelJ. H. M. Poorthuis
}

$\mathbf{1}$

Introduction

Converts to Catholicism cherish certain books in which a passionate religious fervor goes along with a highly individual orientation. At first glance this personal experience seems to be characterized by a thoroughly orthodox orientation, but on closer scrutiny the borders of institutionalized Catholic religion are often transcended from the very moment of entering into the holy Mother Church. Next to the Confessions of Saint Augustine, Die Letzte am Schafott [The song at the scaffold], by Gertrud von le Fort (1876-1971), a convert herself, belongs to the favorite conversion literature.

It would be easy to dismiss the theme of this book, Die Letzte am Schafott, as no more than an expression of a Catholic triumphant attitude. During the French revolution, possessions of convents were confiscated and whoever resisted was sentenced to death and executed under the guillotine. The French Revolution would be no more than a demonstration of the barbarous attitude of the idolatry of Reason over against the devotion to true faith. The story, however, goes far deeper than that. This becomes clear when we focus on two of the main characters: Two young girls, strongly differing in temperament and background; and two spiritual leaders in the convent diametrically opposed to one another. We will note that the story contains a sharp criticism of traditional Catholic ideas about self-sacrifice and martyrdom. Simultaneously, the story offers a passionate picture of true martyrdom, which can only be reached by acknowledging existential fear and a deep love of life.

\subsection{Bringing a Sacrifice Willingly and without Struggle is not a Sacrifice}

First I want to clarify in which way the story of the Carmelites can be connected to the story of Abraham called upon to sacrifice his own son, as told in Quran and Bible, with or without elaboration in the midrash, the Jewish interpretations of the Bible. The primary message of the story is that the sacrifice of the son is initially commanded, but should not be executed eventually. God demands surrender from Abraham, but not at the expense of his own son. Full humanity can go together with full surrender to God, as the story could be 
summarized. Abraham's awakening conscience during the story would convey precisely this insight.

It is, however, vital to realize the paradoxical character of the sacrificial act. Some interpretations depict Abraham as a real paragon of obedience, to such an extent that it almost seems as if it were his only wish to sacrifice his son. This would totally rob the sacrifice of its dynamism! Suppose Abraham was secretly thinking: "Thank heavens, I cannot wait to sacrifice my son". ${ }^{1}$ This would give us a shudder of abhorrence. Apparently, a sacrifice can only retain its significance as sacrifice when it is actually too precious to be made. The willingness to sacrifice to God might nearly obscure this essential fact. Only when the sacrifice is as precious as one's own life - or even more - devotion to God can have a meaning. This implies that no sacrifice made out of hatred of life and out of contempt of oneself can be regarded as a sacrifice.

Hence, the sacrifice affirms in a paradoxical way the very human desire to retain the sacrifice. Asceticism, fasting, and other transformations of sacrifice retain their significance only as affirmation of love for life, of enjoyment of human existence, expressed in eating and drinking and in sexuality. The rest is nothing but self-mutilation and a not outgrown asceticism. Even celibacy and sexual abstinence need to affirm bodily affections as of great value, or rather they would serve as a foil for the hatred of life and the body.

Let us now turn to the story of the Carmelites. Although it has a historical kernel, it became famous as a novel, as a film script by George Bernanos, and as an opera by Francis Poulenc, Dialogues des Carmélites.

\section{Die Letzte am Schafott ${ }^{2}$}

This is historical: Carmelite sisters resist the confiscation of their convent during the French revolution. Sixteen sisters are condemned to death. In 1906, these sisters have been beatified. Gertrud von le Fort wrote her novel, Die Letzte

1 A variety of sources such as the well-known painting by Rembrandt of Abraham sacrificing Isaac (in the Hermitage in St. Petersburg) as well as a Syriac dialogue poem about Genesis 22 allude to a certain cruelty in Abraham without, however, pushing it so far as to rob the sacrifice of its meaning. See S. Brock, "Two Syriac Verse Homilies on the Binding of Isaac," in Le Muséon 99 (1986), 61-129. A psychoanalytical interpretation of the story as the struggle between father and son also tends to assume a certain willingness in Abraham to sacrifice.

2 Gertrud von le Fort, Die Letzte am Schafott (München: Ehrenwirth Verlag, 1931). I use a 1953 version. English translations are mine. See as well Gertrud von Le Fort, The Song at the Scaffold, translated by Olga Marx, New York 1933 . 
am Schafott, in 1931 when she felt how the rise of the totalitarian regime of Nazism threatened human existence as well as the integrity of the Church. She was shocked to see the nazi pamphlets against the Jews in München, which gave her an inkling of impending disaster. It was Von le Fort's conviction that the Church should resist. ${ }^{3}$ She was herself persecuted by the nazis. Georges Bernanos (1888-1948) wrote the script after the war, in a climate of existentialism in which people were torn between meaning and absurdity. He grappled with the question how humankind in its tragic condition could acquire God's grace. ${ }^{4}$

The composer Francis Poulenc (1899-1963) was moved by a religious experience and wrote his opera based upon Bernanos' text, but with important modifications. ${ }^{5}$ The music, the text and the theatrical scenery all contribute to make it into a work of art in its own right. Because of the multiple meanings the qualification 'dialogue' is aptly chosen. The focus of the opera is the entanglement of fear and religion on a neurotic and existential level, embodied in the different protagonists. ${ }^{6}$

I limit myself to the novel of Gertrud von le Fort, who relates the story from the vantage point of a contemporary witness of the events. Only here and there I point out differences with the other versions in so far as these differences shed a new light upon the meaning of sacrifice.

\subsection{The Story of the Carmelite Nuns}

The story tells about two girls who differ strongly in character: The lively and happy Constance and the aristocratic Blanche filled with fear and depression. Blanche's mother was harassed by a mob when heavily pregnant. She died shortly after she gave birth to Blanche, because of which Blanche's life is under a bad omen. Several objects in her house imbue her with fear, such as an old staircase. Her governess tries to combat these fears by religious education. Praying to the "little King with the crown", that is, to Christ, should guarantee protection. Blanche wonders what would happen if the crown fell of his head.

3 See Gail Elisabeth Lowther, A Historical, Literary, and Musical Analysis of Francis Poulenc's "Dialogues des Carmélites" (PhD diss., University of Ohio, 2010), 14.

4 Georges Bernanos, «Dialogues des Carmélites, in Oeuvres Romanesques (eds G. and M. Estève; Paris: Gallimard, 1961), 1567-1719.

5 Francis Poulenc, Oeuvres lyriques, EMI classics, Edition du Centénaire 1899-1963.

6 See the excellent article by Hans Alma and Hetty Zock, "The Mercy of Anxiety. A RelationalPsychological Study of Dialogues des Carmélites," in Mental Health, Religion \& Culture 4 (2002): 175-192. Cf. Sister Meredith Murray, La génèse du Dialogue des Carmélites (Parijs: Editions du Seuil, 1963). 
The governess gets confused and assures that the staircase is really safe when you have said your prayers. At that moment, a bar breaks in Blanche's hands.

In marked contrast, Constance is so cheerful and merry - a genuine child of God - that she seems to know no fear of death at all. Sometimes she alludes to an early death in order to be with God sooner. It is hard to conceive of a greater contrast than between the characters of these two girls. Still, in a mysterious way their lives seem to coincide. To put it in Jungian terms, they seem to be two split figures of one and the same original or the polar manifestation of tensions existing in each individual.

Blanche's father, who is a freethinker, does not understand his daughter's choice for the convent. He regards it as merely an attempt to escape fear. In spite of that, he continues to support his daughter morally. Although Blanche indeed tries to escape her fears, it becomes clear that entering the convent is hardly a way to avoid anguish. She is received by the prioress who dies shortly afterwards suffering severe pains, a sure indication that life in the convent cannot shut out reality and even less fear. Blanche wonders how God can allow such suffering and because of that her profession of faith is initially met with strong suspicion by the mistress of novices, Sister Mary of the Incarnation. The latter even tries to postpone Blanche's profession. However, an impending new law prohibits the entrance into the convent for new candidates and Blanche is accepted very quickly. This brings great joy to the little sister Constance, who exclaims that the two of them might reach the age of hundred years, "even when it is hard to enter heaven after such a long time". Because of the difficult circumstances, Blanche's religious name will be Sister Blanche of the Agony of Christ. ${ }^{7}$

It is told about sister Mary of the Incarnation that after the execution of some of her fellow-sisters, she would be marked with a red line around her neck. When the narrator meets her, he notes that no such line is visible. The narrator inquires after Blanche and the mistress of novices mutters: "Why should fear and shudder be something bad? Cannot they sometimes probe far deeper than mere courage?". Initially, she doubts Blanche's aptitude to face the perils of religious life, but she secretly offers herself in devotion to God in order to strengthen Blanche.

The commissioner of the Jacobins regards the convent as a hotbed of exploiters and traitors. During his inspection of the convent, Blanche utters a desperate cry. The commissioner is convinced that Blanche would prefer to leave the convent. Sister Mary of the Incarnation intervenes, arguing that the commissioner has no authority to judge these matters. In a grim inquiry,

7 In Bernanos and Poulenc, Blanche chooses that name herself. See Lowther, Analysis, 33. 
the commissioner expresses the hope that the heads of the sisters will one day be put on the stake. Instead of frightening Sister Mary with it, she feels glorified. A glowing fervor burns in her veins, an indication of her longing for martyrdom. She prays for Blanche's martyrdom as well, but without telling her, in order not to burden her with it. Meanwhile, she indicates unmistakably that martyrdom would be the highest ideal for the whole of the community.

Because of the prohibition of the eternal vow, Blanche and Constance are the only two novice sisters. The mistress of novices, Sister Mary, tries to bring the two of them to the eternal vow in secret, with martyrdom as the crowning event. The prioress, however, strongly objects to that idea.

There is a cherished tradition to pass the statue of the Little King along the cells of the sisters during Christmas. This year things will be different: The scepter and the crown have already been confiscated. Blanche is in the grip of fear so intensely that she drops the statue. The head breaks off. Upon the advice of the mistress of novices, the prioress intends to send Blanche away from the convent because of her excessive fear. In a conversation with Blanche, however, the prioress gets the impression that Blanche has devoted her fear of death to God in a religious act, mindful of her religious name: Sister Blanche of the Agony of Christ. The prioress decides that Blanche may stay under her personal supervision. This marks the beginning of a bitter antagonism between the prioress and the mistress of novices. The latter fears that Blanche's weakness and fear would be a good reason for the prioress to avoid martyrdom altogether for all sisters. ${ }^{8}$

\subsection{The Mistress of Novices}

When the prioress leaves for a journey, the mistress of novices takes over the authority over the convent. She announces the assault of the convent. The little Constance starts to cry. Still, she is not afraid, but she, being the youngest, does not want to be the last on the scaffold. Sister Mary, the mistress of the novices, is painfully hurt: "In the order of the convent, the eldest one will be the last", she says, "and besides, you are not the youngest, but Blanche is". She looks at Blanche while emphasizing that no one will be forced to martyrdom. "Whoever is not prepared to give her life to Christ may step aside." She hopes that Blanche will understand this as a kind of invitation, but Blanche remains silent. Later on, Blanche is asked again to step aside and then she remarks: "I want to remain loyal to my fear". During the act of consecration in the chapel,

8 In Bernanos, Sister Constance pretends to belong to the weaker sisters, this in order to protect Blanche. "I do love life so much", she says. 
Constance notes that Blanche kneels next to her. When she looks up again during communion, Blanche has disappeared.

Blanche is taken prisoner by the mob, her father is killed and she is offered a cup of blood in a blasphemous gesture. As both an aristocratic and a religious person, the anger of the mob doubles against her. Market women, "mothers of the revolution, drag her through the streets of Paris". Meanwhile, the prioress has returned from her journey and is leading a second act of devotion. This time, it is no longer an act for "God, king and fatherland", as sister Mary of the Incarnation, herself of royal blood, had wished, but a "sacrifice without hope, a sacrifice for God only, a sacrifice of pure love". Mary of the Incarnation had been convinced that the departure of the weak Blanche would be a blessing for the convent, but this idea does not play any role with the prioress. Then something curious happens. When both the prioress and the mistress of the novices are in Paris, they watch a spectacle of prisoners being carried on carts to the guillotine. Sister Mary exclaims: "O Jesus Christ, now I understand your agony", and she disappears in the crowd. The next day we hear that sister Mary was under the impression that Sister Blanche had been on the cart.

Sister Mary wants to travel back to the convent in Compiègne to be together with the other sisters, but all the roads have been blocked. The sisters are taken prisoner and are deported to Paris. The crowd is searching for Sister Mary because of her royal descent. She, however, brings the "sacrifice of the sacrifice", which means that she renounces martyrdom by hiding. The expression "the sacrifice of the sacrifice" might denote something truly spiritual and even heroic: By renouncing the glory of martyrdom, she would overcome the last traces of egoism. The writer, Gertrud von le Fort, however, appears not to intend this, but adds in a rather ironical vein: "Less noble people might think that she trembled for her life". "The more pious people" - without stating it explicitly, Gertrud von le Fort considers them naïve - thought that this was the greatest sacrifice to renounce the crown of glorious martyrdom. There is a clear suggestion that Sister Mary has eventually chosen for the easiest road, namely, to safety.

Still, later on she is persuaded that the sisters will chant a hymn on their last way and she wants to join them together with the priest who was connected to the convent. The priest forbids this and says that she should sacrifice her voice as well. "Think of the loneliness of Christ in the Garden of Olives. And think of mother Mary's silence." ${ }^{\prime 9}$ The novel continues: "From that moment on, Sister

9 In Bernanos and in the opera of Poulenc, Sister Mary says: "Their last glance will search me in vain!", whereupon the priest retorts: "Think of another glance to which you may direct yours." 
Mary of the Incarnation remained utterly silent. Her voice was transferred to someone else".

\section{$2.3 \quad$ The Hymns}

Indeed the sisters sing a hymn, the Salve Regina, to mother Mary. After that, the Veni Creator Spiritus is heard, the hymn to the creative Holy Spirit. It is as if the destruction and chaos caused by the machinery of the guillotine is checked by the creative force of the Spirit. The sound of the choir of the sisters becomes thinner during the operation of the guillotine. In the end, only one voice remains, that of Sister Constance. When her voice is muted as well, another voice can be heard out of the crowd. The voice of Sister Mary has indeed been transferred to someone else. The voice sings without any trembling and rather exultingly until the end of the last strophe:

Deo Patri sit gloria

Et Filio, qui a mortuis

Surrexit ac Paraclito

In saeculorum saecula!10

The 'Amen' could not be heard any more. Blanche was beaten to death by the raging mob. ${ }^{11}$ The narrator was a witness of this execution and relates the whole history in a letter to a friend. He comments that it is not the high value of human nature which has come to light in this story, but the decline of humanity giving way to chaos. Blanche was not a heroine, but demonstrates the fragility of our force and dignity.

\subsection{The Narrative Lines in the Story}

Blanche is tormented by fears. Her religious education has taught her to pray to Jesus, who will offer protection in exchange. However, in many smaller details - the broken bar of the stairs, the crown of the little King falling on the ground - it becomes clear that this religious bargain does not hold. Prayer in exchange for safety does not constitute the essence of Christian spirituality. Blanche's way to the convent is by no means an escape from fear, but will

Then both leave the stage. Is a liaison between both suggested here? In that case, the ultimate degradation of Sister Mary would be complete!

10 Glory be to God the Father,/ And to the Son, who has risen from the dead,/ And to the Spirit who consoles, / For ever and ever!

11 Bernanos describes how Blanche is pushed to the scaffold among a group of women, after which her voice remains silent. Poulenc, however, describes how she climbs the scaffold. 
rather intensify fear. This becomes clear when the old prioress is not spared pains by God. The religious name of Blanche of the agony of Christ, indicates that Blanche, with all her excruciating fears, is closer to Christ than the selfassured Sister Mary of the Incarnation. ${ }^{12}$ Sister Mary has no sympathy at all for Blanche - she can hardly be called a "mother Mary" - and she accuses her of having small faith. Her own steadfastness, however, is 'cheap', because it lacks a basis in a genuine experience of anxiety as will become clear in the sequel of the story.

When the commissioner threatens the sisters with death, Sister Mary glows with an inner desire for martyrdom. Blanche remains loyal to her own anxiety and does not opt for the heroism of martyrdom. Sister Mary's longing for heroism is mingled with pride of her royal descent and her affiliation with the royal house of France, which renders her willingness somewhat insincere. She attempts to remove Blanche from the community as a weak element which eventually undermines her own willingness to sacrifice. Sister Mary is unable to identify with her community of sisters, but her pursuit is a private glory and salvation. In this respect, she is diametrically opposed to the new prioress who rejects the imposed act of devotion to martyrdom and takes Blanche under her personal protection.

It is highly symbolic that Blanche admires the statue of the little King of Glory because of its smallness and fragility, whereas Sister Mary reproaches her for not calling the little King powerful. Blanche rejects this 'correct' Christian qualification and says: "The little King is dead. What remains is the Lamb of God". She may refer to a victory over death, but only through fragility, suffering and death. Blanche's fellow sisters have to appear in the revolutionary court because they "do not recognize" the authority of the law. Blanche is absent. However, Sister Mary is nowhere to be found either. The sisters are condemned to the guillotine because of "counterrevolutionary statements that constitute a danger to the state". When the verdict is executed, the sisters start to sing. At the moment it would have been Sister Mary's turn, suddenly Blanche's voice is heard in the crowd. In spite of her anxieties, Blanche raises her voice in the midst of the crowd and is killed.

12 In Bernanos and Poulenc, there is an elaborate debate about how it could be that Christ felt a profound fear of death, while many saints faced death without any fear. 
The story contains quite a few antagonistic movements, which can all be explained as ways to clarify the essence of self-sacrifice. Sister Mary is utterly convinced of the importance of self-sacrifice and wants to promote that among the sisters as their vocation. Self-sacrifice appears not as a personal choice in life, but as a collective ideology imposed "from the outside" by Sister Mary with considerable constraint. Sister Mary does not feel any motherly love, in spite of her name, but demands self-sacrifice of her 'children', in marked contrast with the prioress who rejects the collective act of devotion to martyrdom and would rather save her 'children'. According to the prioress, martyrdom is a gift from God, not something that can be achieved by humans out of free will if there are other options as well..$^{13}$ Blanche cannot surmount her fear and disappears. Her disappearance marks the beginning of her Via Dolorosa. Eventually sister Mary also discovers what anxiety really is and then it is her turn to disappear. Her later attempt to join the other sisters does not succeed either. In Bernanos and Poulenc, Sister Mary and the aforementioned priest disappear simultaneously, so that a connection - or rather a liaison - between them is suggested. This would mean a total desertion. Sister Mary's initial willingness to sacrifice herself cannot be explained as a victory over her fears, but constitutes their denial. Hence this sacrifice is not a genuine sacrifice, but arises out of lack of love of life. Her refusal to bring the sacrifice constitutes a first positive discovery of that love of life, after which she recoils from the genuine sacrifice which presupposes it. Sister Mary betrays her own ideology, in spite of the fact that she constantly reproached Blanche for not embracing martyrdom.

No doubt this denouement constitutes a sharp criticism of martyrdom as a collective Catholic ideology, imposed as it were "from the outside" instead of being a free choice "from the inside". ${ }^{14}$ Gertrud von le Fort does not shrink back from a highly critical stand on outward morality and a legalistic sense of duty, in which personal feelings of individuals do not count. The novel is by no means a paean of traditional Catholic triumphant devotion.

Religious substitution interpreted as the responsibility of each individual for the whole of humankind is an essential theme in the literary works of Gertrud von le Fort. Sacrificial death is regarded as participation in the redemption

\footnotetext{
13 Poulenc emphasizes this element.

14 This seems to me a striking parallel with Levinas' philosophy, which does not offer a perspective of sacrifice and martyrdom as generally valid, but radically rejects any martyrdom in so far it is preached to someone else. See E. Levinas, Humanism of the other (Chicago: Urbana, 2003), 31.
} 
by Christ. Although Protestantism emphasizes that humankind cannot add anything to Christ's redemptive suffering, Catholic theologians such as Erich Przywara (1889-1972) have emphasized the significance of vicarious suffering for all believers "in Christ". 15 In French literature around 19oo, there is a remarkable flood of Catholic literature on vicarious suffering, which has sometimes been branded as a "reactionary revolution". ${ }^{16}$

Gertrud von le Fort can be interpreted as both a continuation and a critical reassessment of this theological tradition. In her works, the danger of a stereotypical view of woman as particularly called to vicarious sacrifice is never far off. Nevertheless the strong differences between the female characters in Die Letzte am Schafott prevent an essentialist approach and do not allow for an easy feminist disqualification. The chasm between an essentialist labeling "from the outside" leading to oppression, and a genuine discovery of one's vocation "from the inside" leading to redemption forms a crucial theme in her writings.

\section{Christian Conceptions of Martyrdom}

The theme of martyrdom as formulated in Die Letzte am Schafott is quite untraditional and even exceptional in comparison with the most important Christian documents from the formative period of Christianity. In a passionate discourse, Ad martyres (198 CE), Tertullian exhorts the Christians who have been taken prisoner to face martyrdom without fear and with total equanimity. Fleeing is no option for Tertullian and feigning obedience to the emperor he rejects full of contempt. Tertullian admires the Stoic ideal of equanimity and a dispassionate attitude, even with pagan heroes such as Lucretia, Mucius Scaevola and Empedocles, and demands no less from his fellow Christians.

The Christian writer Origen, who lived somewhat later than Tertullian, had to be prevented from martyrdom as a child, when his father had been taken prisoner and he himself wanted to achieve the crown of martyrdom. In his Exhortation to Martyrdom ( $235 \mathrm{CE}$ ), he also sketches equanimity as the highest ideal, embodied in the Jewish seven Maccabaean martyrs. Remarkably, Origen discusses the problem that Christ might have felt a strong fear of death, as the

15 Helena Saward, "A Literature of Substitution: Vicarious Sacrifice in the Writing of Gertrud von le Fort," German Life and Letters 53:2 (2000): 178-200. Incidentally, both Przywara and Gertrud von le Fort were in contact with Edith Stein.

16 Richard Griffiths, The Reactionary Revolution. The Catholic Revival in French Literature 1870-1014 (London: Constable 1966), esp. 149-222. 
prayer testifies: "Father, if it be possible, let this cup pass from me" (Matt. 26:39). It is telling that Origen tries to explain this away (\$29). We have to wait until Cyprian $(200-258 \mathrm{CE})$ for the argument that martyrdom, although the highest good, should not be searched, but - if possible without denying the Christian faith - should be avoided. This was to become the guiding principle for the Church afterwards. Incidentally, Cyprian died as a martyr.

\subsection{Rejection of a Stoic Attitude}

Die Letzte am Schafott can be read as a consistent major critique upon the Stoic ideal of equanimity towards martyrdom. Christ's fear of death is not a reason for embarrassment to the writer of the novel, as it was for Origen, but points the way to a genuine experience of one's own fear of death that has to be lived through. The prioress alludes to martyrdom not as an achievement but as a gift from God; this against Sister Mary who deliberately wants to search martyrdom, hereby suppressing her own fears.

In contrast, Blanche chooses for her own feelings and for her love of life, which she feels in spite of (or thanks to) her fears. Her continuous fear of death coincides with a strong desire to live. Again we see in the story an antagonistic movement. The first movement was that of Sister Mary towards heroic martyrdom, combated by the prioress, while the second is that of Blanche herself, fleeing for martyrdom, but nonetheless gently connected to Sister Constance. The anxious Blanche will eventually choose martyrdom out of her own free will and without anybody counting upon it - except Sister Constance. Blanche's choice is not motivated by a morbid love of death - she has proven that by her flight - but out of loyalty to her vocation to be a nun and a bride of Christ. She does not want to abjure her habit and her community of fellow sisters. In that respect, her deed might be comparable to that of the other sisters, but in the novel we do not get more information about their motives. ${ }^{17}$

As modern human beings, we might shiver by this story of martyrdom of the sisters, convinced as we are that religious choices must be reduced to social pressures, gender differences, unconscious motives due to childhood experiences, hatred of life or a secret ambition to heroism. That this martyrdom could be understood out of genuine love of life and as a testimony to Christian faith is hard for us to accept. We might even propose a religious frenzy in order to rob this religious gesture of its authenticity. Blanche's history seems to forestall all this by anticipating these objections. In first instance, as we all would do spontaneously, she avoids her fate. The childhood experiences, the social

17 Bernanos introduces extensively other sisters with name and background, who all have their own perspectives upon the events. 
pressure and even the unconscious craving for glory are all given their due. This confers to Blanche's deed precisely that hallmark of authenticity: A personal wrestling with her vocation, the loving embrace of life itself which makes her surrender of her life to God the most precious gift.

Her anxieties and fears, which initially seemed a weakness and a hereditary curse, turn out to be so essential to her choice that without them her choice would lack humane traits. Hence, the self-sacrifice in martyrdom is no longer an automatic step, but a long way of growth and defeat of one's own fears. Existential fear and the search for identity are closely intertwined here. Not by neglecting fear, but by integrating it into the love of life as a gift from God, Blanche affirms her own identity and honors her own name Blanche - in reference to her white habit. Her deed turns out be pure freedom and pure devotion to God, a combination rarely achieved. This is her great strength, referred to in her name as well: Blanche de la Force, simultaneously reference to the author's name, Von le Fort. The irony of the story is that all ideals of Sister Mary of the Incarnation were based upon her own strength, whereas Blanche realizes these ideals based upon God's grace. This is symbolized by the voice of Sister Mary being taken over by Blanche.

Next to Sister Mary, Blanche and the prioress, there is the young and cheerful Sister Constance. It is as if she is not antagonistic to any person and manages to live without conflict. Her entrance into the convent is motivated by love of God and humankind, whereas Blanche is motivated by fear of life. Together they form a mysterious couple. Both are novices, both wonder whether they will be the last ones on the scaffold. ${ }^{18}$ Constance is convinced that Blanche will return in one way or another, although she puts no pressure at all upon Blanche as Sister Mary did. We noted earlier that a dream had told Constance that the two of them would die together. With an inner joy Constance enters the scaffold, without being forced by an ideology imposed upon her by a tradition or a superior. Pure love of God and humankind motivates her behavior. Her face radiates joy. It is that joy which Blanche has to conquer, but which will eventually be her share as well. ${ }^{19}$ Constance has always encouraged Blanche, stating that she would be able to overcome her fears. In the end the two of them are together, united in death before God.

18 Poulenc intensifies the intertwined fates of Blanche and Constance by introducing Constance relating laughingly a dream in which Blanche and herself will die together.

19 Poulenc describes how Constance and Blanche exchange a last eye contact before Constance's execution. 


\section{$5 \quad$ The Complex Relation Between Sacrifice and Freedom of Will}

We might wonder what prompted Blanche to raise her voice in the midst of the crowd. At first glance death could have been avoided, in contrast to the fate of the other sisters. It is significant that Blanche does not decide to choose martyrdom before she sees her fellow sisters, but precisely at that moment. This may indicate that she felt her personal vocation to be intrinsically connected with them. At the moment she sees the other sisters being carried off to the scaffold, she realizes that she is on the brink of deserting her vocation. Her choice is free but not individualistic: Her identity is intrinsically connected to the community, yet this does not imply that she is consciously pressed by that community. Here we might adduce the philosophy of René Girard, who points out that our desires have an element of imitation. ${ }^{20}$ We desire when and what we see others desire. Blanche has probably no desire of martyrdom, until she sees her fellow sisters on the way to the guillotine. Then she manages to overcome her fear of death.

Should we conclude that her martyrdom is after all not a free decision but rather a form of mimesis, of imitation of what others do in order to acquire the same status? It is important to look once more at her situation.

She does not distance herself explicitly and visibly from the vocation of her fellow sisters. At that moment she is hidden in the crowd, be it in the hands of a revolutionary mob. ${ }^{21}$ In whatever way, she is now invisible to the eyes of the other sisters. Neither the crowd nor her fellow sisters did have occasion to put any pressure upon her final choice. Therefore her release from the crowd by following her vocation should be understood as an act of pure freedom, "from the inside". It is a self-sacrifice without being sacrificed. As the example of her fellow sisters has brought her to this step, it is preferable to speak about following in their footsteps rather than copying their fate. Even if it is the fate of the others that induces her to take up martyrdom, she is not forced by the conscious will of the others. Hence it is neither slavish mimesis nor imposed force or collective obligation, but a choice for martyrdom which she - and she only recognizes in her fellow sisters and which ultimately only she can choose for herself. Seen in this perspective, she realizes the highest freedom and the deepest identity by choosing self-sacrifice, after having lived through all the fears and sufferings as well as the feelings of attachment to life. We may regard her self-sacrifice as a genuine sacrifice, in the sense of sacrifice with

\footnotetext{
20 See Saskia van Goelst Meijer's contribution in this volume.

21 In Gertrud von le Fort's novel. Bernanos and Poulenc put a stronger emphasis upon Blanche's freedom by introducing the mob only after her singing.
} 
which this chapter opened: Self-sacrifice presupposes love of life, or else it is no sacrifice. Fear does not appear as a disturbance of psychic life that should be removed. Fear leads Blanche to the deepest kernel of her life and to the highest consciousness of her vocation. ${ }^{22}$

And yet, we have to leave the paradox unresolved that Blanche's attitude cannot be turned into a general ideal to be recommended to all mankind. Expecting the self-sacrifice from others amounts to immorality. ${ }^{23}$ Blanche's resistance to such a generalized ideal, embodied in Sister Mary of the Incarnation, remains valid until the very end. Even the notion of divine reward for martyrdom should be challenged, to avoid the reduction of an unselfish act into an 'economic' choice for what would be most beneficial. ${ }^{24}$

Poulenc ends his opera with a female choir that is considered the most heartrending music ever written. The music, a Latin hymn sung by the women and accompanied by the orchestra is repeatedly interrupted by the brutal thwack of the guillotine, after which the choir has one voice less. At the end we only hear the voice of Constance, who ends up being murdered as well. Then there is Blanche's solo voice, singing the final lines of the hymn Veni Creator Spiritus while entering the scaffold. ${ }^{25}$ She does not sing the final word 'Amen', however. At that moment the guillotine falls down on her too.

22 Cf. the existential meaning of fear in Kierkegaard and Heidegger. See J. Calsius, Ruimte voor angst. Het vermogen tot existentiële bewustwording doorheen angst in relatie tot lichaam en authenticiteit (Room for Fear. The Ability to Existential Consciousness through Fear in Relation to the Body and to Authenticity), (PhD diss., University of Utrecht, 2011).

23 In that respect, the philosophy of Levinas does not contain a general sacrificial philosophy, but rather stresses the impossibility to expect self-sacrifice from someone else but me. A different position in: Peter Jonkers, "Justifying Sacrifice," Neue Zeitschrift für systematische Theologie und Religions-philosophie, 50 (2008): 313-329.

24 This does not imply an atheistic stand as the only morally possible position, as John Milbank seems to believe. ("The Midwinter Sacrifice: a Sequel to Can Morality be Christian?" Angelaki 6, 2 (2001): 49-65. Those who act unselfishly without the motivation of heavenly reward are the most deserving that reward. This seems to be the lesson of the question of the righteous to the heavenly Son of Man (Matt 25:37).

25 In the novel Blanche is killed by a furious mob, by which her fate and her mother's fate coincide. Bernanos, and even more Poulenc, have chosen to establish a stronger connection between Blanche's fate and that of her fellow sisters. 